\title{
Entangled industrialization. The EEC and industrial development in Francophone West Africa
}

\author{
Martin Rempe \\ University of Konstanz
}

\subsection{Industrialization and entanglement}

Industrialization played a significant role as a development strategy in the global, post-colonial development-discourse during the 'first development decade' heralded by the United Nations in 1961. Whereas colonial powers such as France and Great Britain had remained rather reluctant with respect to state-led industrialization in their colonies, modernization theorists and development economists considered a planned and comprehensive industrial policy a key factor for staging growth. Clark Kerr's Industrialism and Industrial Man, published in 1962, was only one of numerous studies that reflected, and at the same time guided, government strategies in the 'North', as well as in the 'South' in their efforts to overcome 'backward' or 'traditional' social structures of the developing countries. Thus, in the era of decolonization, industrialization became not only a key concept with which to foster social change, but also a strategy of global convergence: it was assumed that through industrialization, nation-states all over the world would sooner or later converge to one model of society, what Walt Rostow called 'the age of high mass consumption'. ${ }^{1}$

${ }^{1}$ Clark Kerr, Industrialism and Industrial Man. The Problems of Labour and Management in Economic Growth, London: Heinemann (1962); Walt W. Rostow, Stadien wirtschaftlichen Wachstums. Eine Alternative zur marxistischen Entwicklungstheorie, Göttingen: Vandenhoeck \& Ruprecht (1960); Patrick Karl O' Brien, 'Industrialization', in: Jerry H. Bentley (ed.), The Oxford Handbook of World History, Oxford: Oxford University Press (2011), pp. 304-324; on the modest significance of industrialization in colonial development see Herward Sieberg, Colonial Development. Die Grundlegung moderner Entwicklungspolitik durch 
Against this global backdrop, the European Economic Community (EEC) also engaged in industrial development outside Europe: the Association of the Overseas' Countries and Territories to the EEC, which was mainly comprised of former French colonies in Africa, provided the legal framework for an active industrial policy as part of the Community's development policy. Even if the implementation of industrial development projects turned out to be relatively modest compared to agricultural and infrastructural activities taking place between 1958 and 1975, the EEC did embark on distinct strategies in terms of industrialization in Francophone Africa from the beginning of the Community's existence. Focusing on overall industrialization plans and on the implementation of two projects in Senegal during the 1960s and 1970s, this chapter will shed some light on these early efforts, including the scientific base on which they were constructed, the ensuing political frictions, the actual economic outcomes, and their shortcomings.

In contrast to Eurocentric accounts that highlight the insignificance of the Community's early industrial development policy, it is argued here that these plans and their partial implementation had a considerable impact on industrialization in Francophone Africa. What is more, a critical historicization of entangled industrial development efforts puts into question widespread assumptions of both contemporary social sciences' analysis and historical accounts, which both maintain that post-independent industrial development in Africa was shaped mainly by national prerogatives and policies. Usually founded on national empirical data, these studies did not care for mutual exchange, for the flow of concepts or for the shared implementation of industrialization projects. $^{2}$ In contrast, an entangled, actor-centered analysis of industrialization efforts in Africa not only escapes contemporary history's

Großbritannien 1919-1949, Stuttgart: Franz Steiner (1985) and Jacques Marseille, Empire colonial et capitalisme français. Histoire d'un divorce, Paris: Albin (1984).

${ }^{2}$ See, for example, Jürgen Donges and Lotte Müller-Ohlsen, Außenwirtschaftsbeziehungen und Industrialisierung in Entwicklungsländern, Tübingen: Mohr (1978); David K. Fieldhouse, Black Africa 1945-80. Economic Decolonization and Arrested Development, London: Allen \& Unwin (1986); James Foreman-Peck and Giovanni Federico (eds.), European Industrial Policy. The Twentieth Century Experience, Oxford: Oxford University Press (1999); for Senegal's national development policy see Mamadou Diouf, 'Senegalese Development. From Mass Mobilization to Technocratic Elitism', in: Frederick Cooper and Randall Packard (eds.), International Development and the Social Sciences. Essays on the History and Politics of Knowledge, Berkeley, CA: University of California Press (1997), pp. 291-319. 
danger of retelling established narratives, ${ }^{3}$ but also points to concrete, exogenous factors beyond the scope conditions usually examined, such as the world market or environmental issues. This approach, therefore, provides a more balanced account of industrial policy in Francophone West Africa.

The chapter proceeds in three steps: first with a sketch that details the background of the Association of the Overseas' Countries and Territories to the EEC, including the statistical record of its industrial policy in Francophone Africa; second with an analysis of the making of the EEC's general industrialization plans; third with a discussion of three case studies in Senegal in the 1960s and 1970s that offer great insight into the reasons why large scale industrialization did not gain ground in Francophone Africa.

\subsection{The official record of the EEC's industrial development policy}

The Association of the Overseas' Countries and Territories to the EEC was one of the most controversial topics addressed in the negotiations leading to the Rome Treaty in March 1957. Still a colonial power, France, backed by Belgium, insisted on a financial contribution of the prospective community to the development of its African territories and threatened to block the integration project altogether if the Association was not accepted. On the other hand, West Germany and the Netherlands had little economic interest in this part of the world. Moreover, they feared involvement in French colonial affairs. Primarily strategic considerations with respect to the Cold War, as well as the lurking failure of the negotiations, led Bonn and Den Haag to give in to French demands. A compromise was made in which a preferential trade area with the associated countries as well as the establishment of a European Development Fund (EDF) was allowed for. The latter was planned to be in effect for a period of five years and was funded by all member states, with Germany and France as the major payers: out of 581.5 million units of account (u.a.), the two countries spent 200 million u.a. each. ${ }^{4}$

${ }^{3}$ Rüdiger Graf and Kim Christian Priemel expand on this danger in 'Zeitgeschichte in der Welt der Sozialwissenschaften. Legitimität und Originalität einer Disziplin', Vierteljahrshefte für Zeitgeschichte 26 (2011), pp. 479-508.

${ }^{4}$ Urban Vahsen, Eurafrikanische Entwicklungskooperation. Die Assoziierungspolitik der EWG gegenüber dem subsaharischen Afrika in den 1960er Jahren, Stuttgart: Franz 
Although most African countries had gained independence by 1960 , the Association was continued and a renewal was supposed to be negotiated between European states and the now sovereign African states. Tenacious bargaining followed, primarily between the European states themselves, before the first Yaoundé Convention was signed in July of 1963. New institutions, such as the Association Council, were founded with the intent to demonstrate that the new Association put the countries involved on equal footing with each other and that the relationships had broken away from their colonial traditions. Moreover, a second European Development Fund, again designed for a period of five years and amounting up to 800 million u.a., was launched. In 1969, the second Yaoundé Convention brought little change to the general design of the Association. The third EDF had only slightly more money to invest (around 1 billion u.a.), but its financial instruments were made more flexible in terms of loans and risk capital. It was only the British entry to this Association in 1973 that brought major transformations of the Association, and subsequently led to the age of the so-called Atlantic-Caribbean-Pacific Partnership, which was established by the first Lomé Convention in $1975 .^{5}$

As Table 10.1 shows, the fund's statistical record of genuine industrial projects between 1958 and 1975 remained very modest compared to agricultural or infrastructural projects: the first fund spent less than 1 per cent on industrial activities, the second less than 6 per cent and the third only a little more than 7 per cent. A specific view on Senegal makes it clear what these figures could have meant from an African national perspective: whereas the first fund did not include any investment at all in the West African country, the second funded only two studies on small industrial business possibilities and the erection of an iron ore factory on a budget of less than 50,000 u.a. ${ }^{6}$ The data for the early 1970s are hardly different: in the official programme for Senegal,

Steiner (2010); Guia Migani, La France et l'Afrique sub-saharienne, 1957-1963. Histoire d'une décolonisation entre idéaux eurafricains et politique de puissance, Brussels: Lang (2008); Thomas Moser, Europäische Integration, Dekolonisation, Eurafrika. Eine historische Analyse über Entstehungsbedingungen der Eurafrikanischen Gemeinschaft von der Weltwirtschaftskrise bis zum Jaunde-Vertrag, 1929-1963, Baden-Baden: Nomos (2000).

${ }^{5}$ Moser (2000), Europäische Integration.

${ }^{6}$ DG VIII, 'Situation des projets du 2ème FED en execution', 30 September 1970, Historical Archives of the European Union (HAEU) 25/1980-1362, 46; DG VIII, 'Résumé de la situation du Sénégal', February 1972, HAEU 25/1980-1328, 367, here 380 . 
Table 10.1 Sectoral disbursement of the European Development Fund, 1958-1975

\begin{tabular}{lrrrrrr}
\hline & \multicolumn{1}{l}{ EDF I } & \multicolumn{2}{l}{ EDF II } & \multicolumn{2}{l}{ EDF III } & \\
\cline { 2 - 7 } & $\begin{array}{l}\text { Unit of } \\
\text { account } \\
\text { (thousands) }\end{array}$ & in \% & $\begin{array}{l}\text { Unit of } \\
\text { account } \\
\text { (thousands) }\end{array}$ & in \% & $\begin{array}{l}\text { Unit of } \\
\text { account } \\
\text { (thousands) }\end{array}$ & in \% \\
\hline $\begin{array}{l}\text { Industrialization } \\
\text { Rural Production }\end{array}$ & 4175 & 0.73 & 40,225 & 5.61 & 45,598 & 7.15 \\
$\begin{array}{l}\text { Infrastructure 1 } \\
\text { Educational }\end{array}$ & 346,847 & 60.75 & 310,947 & 43.32 & 274,853 & 43.11 \\
$\quad 11,043$ & 19.45 & 70,092 & 9.77 & 66,328 & 10.4 \\
Othaining & 14,729 & 2.58 & 29,489 & 4.11 & 61,918 & 9.71 \\
Total & 570,902 & 100 & 717,672 & 100 & 637,663 & 100 \\
\hline
\end{tabular}

${ }^{1}$ Infrastructure encompasses transport communication, health, water engineering and urban infrastructure.

Source: Carol Cosgrove-Twitchett (1978), p. 136.

Table 10.2 Loans from the European Investment Bank for industrial projects in the associated countries in Africa, 1964-1975

\begin{tabular}{lcc}
\hline & Loans in unit of account (millions) & Number of projects \\
\hline Ivory Coast & 21.54 & 6 \\
Cameroon & 17.27 & 9 \\
Congo & 9.0 & 1 \\
Gabon & 0.91 & 2 \\
Upper Volta & 0.45 & 1 \\
Mauritania & 11.0 & 1 \\
Senegal & 2.43 & 1 \\
Togo & 5.93 & 1 \\
Zaire & 34.2 & 3 \\
\hline
\end{tabular}

Source: Helga Gerth-Wellmann and Dorothee Kayser (1980), p. 73.

not a single industrial project was included. ${ }^{7}$ The same holds true for the record of the European Investment Bank (EIB) during the two Yaoundé conventions: as Table 10.2 indicates, only nine out of the 18 associated African countries profited from an EIB engagement, of which six received modest or only single investments.

In reflection, it might appear that this chapter looks like a case of much ado about nothing: the EEC played no part in the industrial

${ }^{7}$ Ferrandi, Rapport de mission, not dated [1970], HAEU 25/1980-1362, 130, here 132. 
development of Senegal and, irrespective of its role in the development of the Ivory Coast, Cameroon and Zaire, only a marginal one with regard to Francophone Africa as a whole. At second glance, however, it is clear that the statistical evidence is insufficient to paint the whole picture. Statistical analyses are, after all, always the result of individual acts of construction and categorization. Such analyses are founded only on documented events and cold facts, but can tell nothing as to people's intentions and ideas. ${ }^{8}$ In short, statistical records are ill-suited for an empirically grounded assessment of the Community's role in Francophone Africa's industrial development during the 1960s and 1970s. Instead, it seems to be more fruitful to investigate the EEC's ideas and concepts before more thoroughly investigating its industrial cooperation with Senegal. The selection of a (statistically) rather neglected country shall strengthen this argument as, even in such countries, effects of industrial cooperation with the EEC can be clearly identified.

\subsection{From import substitution to export-oriented industrialization: Plans and their shortcomings}

It would be misleading to claim that the Directorate General VIII for development of the European Commission designed concrete concepts on industrial development before the Yaoundé Convention had taken effect in June of 1964. The formative years of the European development policy were mainly characterized by the effects of African decolonization and the renewal of the Association. Apart from the generation of very general reports on African agriculture and social living conditions, and aside from one historical review on capital investments in Africa since the Second World War, there was no statement on this topic worth mentioning. Nevertheless, these reports already show that the DG VIII was clearly in favour of African industrialization, which was reliant on modernized and productive agriculture. ${ }^{9}$

The first systematic approach of the Community to industrialization in Francophone Africa was started at the end of 1963, when the DG VIII

\footnotetext{
${ }^{8}$ Adam J. Tooze, 'Die Vermessung der Welt. Ansätze zu einer Kulturgeschichte der Wirtschaftsstatistik', in: Hartmut Berghoff and Jakob Vogel (eds.), Wirtschaftsgeschichte als Kulturgeschichte. Dimensionen eines Perspektivenwechsels, Frankfurt a. M.: Campus (2004), pp. 325-351; Graf and Priemel (2011), 'Zeitgeschichte'.

${ }^{9}$ Martin Rempe, Entwicklung im Konflikt. Die EWG und der Senegal 1957-1975, Köln: Böhlau (2012), pp. 63-73.
} 
decided to draft a general survey dealing with possibilities of import substitution in the 18 associated African countries. According to the planners surrounding Jean Durieux, the Belgian Director for development studies within the DG VIII, the EEC was not supposed to wait for the governments of the associated states to make industrialization proposals, but was itself to take over the initiative. ${ }^{10}$ The general study plan was to act as a guide for the associated states, the EDF and private industry. The survey focused on the consumer and consumption industries, the two branches that the experts considered the most favourable for the purposes of import substitution.

The import substitution approach was developed, theoretically, by Raúl Prebisch after the Second World War. Its aim was to overcome colonial economic structures that had been based on the export of cheap agricultural goods and the import of finished goods from metropolitan areas. ${ }^{11}$ The experts chose this strategy because of its allegedly simple procedural method: they needed only to evaluate existing needs and markets on the basis of the import statistics of the associated countries in order to decide whether a project would be profitable. ${ }^{12}$ Conceptually, they followed a 'pluri-national' approach that ignored national borders and focused on greater distribution zones. In the final study, the DG VIII made explicit that the aim of the pluri-national approach was a reorganization of the associated countries' restricted markets that suffered from the political decolonization process. As such, this kind of reorganization was to be geared to the geographical structures of the colonial era. ${ }^{13}$ Considered to be an incentive for (now voluntary) regional integration processes, this concept was supposed to correct the 'balkanization process' that accompanied the decolonization of the French colonies in Africa. ${ }^{14}$

${ }^{10} \mathrm{COM}$, Programme d'etudes générales sur les possibiltés d'industrialisation des EAMA, not dated [1965], HAEU 25/1980-1998, 61.

${ }^{11}$ Bernardo Calzadilla and Andreas Novy, 'Importsubstituierende und exportorientierte Industrialisierung', in: Peter Feldbauer (ed.), Industrialisierung. Entwicklungsprozesse in Afrika, Asien und Lateinamerika, Frankfurt a. M.: Brandes \& Apsel (1995), pp. 33-46.

${ }^{12} \mathrm{COM}$, Programme d'etudes générales sur les possibiltés d'industrialisation des EAMA, not dated [1965], HAEU 25/1980-1998, 61, here 65 f.

${ }^{13} \mathrm{COM}$, Rapport de synthèse sur les perspectives d'industrialisation des EAMA, not dated [1967], HAEU 25/1980-1995, 14, here 26.

${ }^{14}$ For more on the balkanization process, see Tony Chafer, The End of Empire in French West Africa. France's successful Decolonization, Oxford/New York: Berg (2002), pp. 163-192; on the EEC's role in African integration processes, see Martin Rempe and Tillmann Schneider, "50 Jahre "Europa" in Westafrika. Zum 
The study was executed by expert institutions from several member states, among them the German IFO Institut für Wirtschaftsforschung and the French Société d'études du développement économique et social. Execution took more than two years to complete, and included two phases of local fieldwork. However, African experts or politicians scarcely participated in this kind of knowledge production. Their role was clearly delineated insofar as they were supposed to only provide information and organizational support. ${ }^{15}$

In the end, the survey presented 109 possible industrial projects that were based on import substitution. However, by the beginning of the 1970s, 156 were being planned. The associated states did not care about the 'pluri-national' setting of these plans, but adopted the proposals within a national framework. ${ }^{16}$ Hence, many projects never outlived the planning stage because, in the course of the European survey, no political dialogue took place that would have acted in favour of the 'pluri-national' approach. Consequently, the whole study, the costs of which amounted to at least 400,000 u.a., ${ }^{17}$ produced virtually nothing, making it useless for donor institutions and interested investors. It was not so much a deliberate decision not to engage in industrial development that accounts for the modest record of the EDF in the 1960s, but errant planning that led to the Community's poor performance. At the same time, this story qualifies the nature of African 'national' industrial policy: whereas the EEC's economic approach of import substitution was warmly welcomed by the African states, they preferred the maintenance of national sovereignty over intra-regional cooperation. This preference, however, eventually forced them to sooner or later resort to European assistance. ${ }^{18}$

Verhältnis europäischer und westafrikanischer Integration', in: Ingolf Pernice et al. (eds.), Europa jenseits seiner Grenzen. Politologische, historische und juristische Perspektiven, Berlin: Nomos (2009), pp. 37-52.

${ }^{15}$ For details, see Martin Rempe, 'EEC Industrialization Plans for Africa in the Sixties', in: Federica di Sarcina, Laura Grazi and Laura Scichilone (eds.), Res Europae. Attori, Politiche e Sfide dell'Integrazione Europea, Florence: Centro Editoriale Toscano (2010), pp. 107-118.

${ }^{16}$ DG VIII, État de réalisation des projets, not dated [1971], HAEU 25/1980-1997, p. 170.

${ }^{17}$ DG VIII, Note, 8 July 1965, HAEU 25/1980-1655, p. 60.

${ }^{18} \mathrm{On}$ the significance of national sovereignty for the post-colonial African state see, for example, Christopher Clapham, Africa and the International System. The Politics of State Survival, Cambridge: Cambridge University Press (1996), pp. 106-113; further, Jean-François Bayart, 'Africa in the World. A History of Extraversion', African Affairs 99 (2000), pp. 217-267. 
Compared to the first Yaoundé convention, the second agreement put a stronger emphasis on industrialization. A closer look at the relevant documents reveals that the 1969 convention twice (in art. 1 and art. 19) declared industrialization to be a central goal of the association, whereas the predecessor only mentioned it in the preamble. ${ }^{19} \mathrm{~A}$ re-start was supposed to be achieved with a new general survey. Officially, the second study aimed at complementing the first one in focusing on possibilities for the establishment and strengthening of export-oriented industries. However, there is no doubt that experience from conducting the first study prompted a different approach and decision-making process. First, the pluri-national approach was abandoned in favour of a purely national framing. Second, the African ambassadors residing in Brussels were more directly involved in the elaboration of the general setting. For example, they participated in discussions on issues like branch selection and, in this way, had a slightly bigger influence on the overall concept than they did in the first survey. ${ }^{20}$ Consequently, as will be shown later on, regular meetings and frequent communication in Brussels led to a higher sensitivity regarding such development initiatives among the African governments.

\subsection{Senegal's experience with industrial cooperation}

It became clear that the success of the European plans, for better or for worse, depended highly on the behaviour and political preferences of the African partners. Hence, these plans are telling with regard to European basic intentions and theoretical convictions of how to foster industrial development, but say rather little about effective industrialization endeavours in Africa and what the Community contributed to them. From a Senegalese perspective, the European industrial policy looked quite different: highly inconsistent, indifferent and sometimes even outright hostile towards African industrialization. This argument shall be exemplified in three industrial projects: truck-manufacture, fertilizer production and the build-up of an export processing zone. These three initiatives were at the heart of the state-led Senegalese industrial policy in the 1960s and 1970s, which was otherwise quite

\footnotetext{
19'Abkommen über die Assoziation zwischen der Europäischen Wirtschaftsgemeinschaft und den mit dieser Gemeinschaft assoziierten Staaten und Madagaskar', Amtsblatt der Europäischen Gemeinschaften no. L 282, 28 December 1970, pp. 2-17, here art. 1 and 19.

${ }^{20}$ Rempe (2012), Entwicklung im Konflikt, pp. 302-305.
} 
reluctant towards state intervention in an industrial sector that was highly dominated by private French enterprises. ${ }^{21}$

The French vehicle manufacturer Berliet erected two construction sites for trucks and public transport vans in Dakar and Thiès in the early 1960s. Following classical import substitution ideas, the goal was to serve the domestic demand and to replace imports coming mainly from France and Germany. Both sites, together, had a utilized capacity of 400 vehicles per year, whereas the domestic demand in Senegal amounted to merely 220 at that time. Consequently, the Senegalese government guaranteed Berliet 90 per cent of the domestic demand and introduced quantitative restrictions on trucks at the end of $1963 .{ }^{22}$

However, the introduction of new quantitative restrictions was not in line with the stipulations of the first Yaoundé Convention. Based on the principles of non-discrimination and reciprocity, the agreement obligated Senegal to abolish trade barriers at the same pace as the European member states would do among each other. There was just one exception made in the event that the omission of customs or quantitative restrictions would hamper the industrialization of the African countries - and it was exactly this exemption to which the Senegalese government referred when Berliet started the manufacturing. ${ }^{23}$

However, the European partner states, as well as the European Commission, strongly disagreed with Senegalese behaviour in this matter for two reasons: firstly, the Yaoundé Convention had, at that time, not yet taken effect; secondly, no consultation, as it was required by the Convention, had taken place in the association committee. ${ }^{24}$ It is certain that, behind these formal objections, were vital economic

${ }^{21}$ République du Sénégal, Plan quadriennal de développement, 1961-1964, Dakar: République du Sénégal (1961); République du Sénégal, Deuxième Plan quadriennal de développement économique et social, Dakar: République du Sénégal (1965); Fieldhouse (1986), Black Africa, p. $213 \mathrm{f}$

${ }^{22}$ CEE Conseil, 'Note 2, 1 June 1966', Archives du ministère des Affaires étrangères français (AMAEF) CE 1961/66-1564; DG VIII, 'Note' 22 September 1965, HAEU 25/1980-906, 25; Interimsausschuss, 'Schlussfolgerungen zur Sitzung der gemeinsamen Sachverständigengruppe EWG/AASM', 6 March 1964, HAEU 19/1969-173, p. 70.

${ }^{23}$ 'Assoziationsabkommen zwischen der Europäischen Wirtschaftsgemeinschaft und den mit dieser Gemeinschaft assoziierten afrikanischen Staaten und Madagaskar', Bundesgesetzblatt II (1964), p. 292, here art. 3, 6; Carol CosgroveTwitchett, Europe and Africa. From Association to Partnership, Farnborough: Saxon House (1978), pp. 97-100; Enzo Grilli, The European Community and the Developing Countries, Cambridge: Cambridge University Press (1993), p. 20.

${ }^{24}$ Grilli (1993), European Community. 
interests of some European member states. Germany's automobile industry particularly felt the effects of Senegal's new restrictions: export figures fell from 160 in 1963, to around 23 in the first half of 1965. Even the French government was not very happy about Berliet's virtual monopoly in Senegal, since it robbed other French manufacturers - like Citroën and Renault - of their market shares. ${ }^{25}$ In short, the French and the Germans were greatly united in their attitude that Senegalese industrialization must not develop in such a way as to injure European exports, a view that can be traced back to colonial times. ${ }^{26}$

Out of these opposing interests emerged a conflict that kept the association committee occupied for more than two years. The Senegalese government opted for a strategy of delay, whereas the European member states were ready to fight for very modest market shares. In the end, Senegal's exemption was accepted as long as the contingent for European manufacturers would not fall under 10 per cent of the total demand per year. ${ }^{27}$

To be sure, the Berliet affair did not have any sustainable effect on the industrialization process in Senegal. Nevertheless, it illuminated the scope conditions for industrial development, being essentially the same for the entire associated Africa: the Community's member states had little interest in an African industrialization based on import substitution that would restrict market access for European products. The Yaoundé Convention gave them a suitable instrument to govern and control this process. In other words, the Commission conducted a general survey based on theoretical assumptions that were by no means backed by the member states. To make matters worse, from the European capital investor's point of view, a settlement in African states without public purchase guarantees was all too risky.

In examining the establishment of a fertilizer industry, the Senegalese predicament is made even more obvious. Again the Senegalese government was at the centre of the project. Put precisely, planning of

25 'Wendland to AA', 3 September 1965, Politisches Archiv des Auswärtigen Amts (PAAA) B 20-1214; 'Heise to Ministry for Economic Affairs', 22 September 1965; 'Moreau to MAES', 26 March 1966, Centre des Archives diplomatiques (CAD) Dakar Ambassade 290; Rat, 'Vermerk', 17 May 1968, HAEU 25/1980-906, 31.

${ }^{26}$ Frederick Cooper, Africa since 1940. The Past of the Present, Cambridge: Cambridge University Press (2002).

${ }^{27}$ Comité d'Association, 'Procès-verbal de la 11ème reunion', 20 September 1966, HAEU 26/1969-325, p. 176, here 210 f., 226 f.; Rat, 'Vermerk', 17 May 1968, in: 25/1980-906, p. 31; Comité d'Association, 'Procès verbal de la 14ème reunion', 16 May 1967, in: id, 26/1969-327, p. 105. 
the project was already long in progress before the EEC listed it in its general survey on import substitution. Already in 1962, a consortium called Société industrielle d'engrais du Sénégal (SIES) was founded as the first fertilizer industry on African soil capable of producing complex fertilizer. ${ }^{28}$ The economic concept of the enterprise was closely bound to the so-called 'production aid' of the Community. This five-year programme, running under the auspices of the first Yaoundé Convention, was intended to modernize Senegal's peanut economy. ${ }^{29}$ The largest share, almost 1.5 billion F CFA, went to fertilizer subventions. These subventions were supposed to act as incentives for the peasants to apply fertilizer and, in the long run, to establish a stable demand for it. The Senegalese government's idea was to kill two birds with one stone: the fertilizer subventions were not only supposed to modernize the Senegalese agriculture, but should, at the same time, serve as initial funding for an important industrial fertilizer manufacturer. ${ }^{30}$

In 1966, after long negotiations, an agreement to construct a new factory with a capacity of 130,000 tons of fertilizer per year between the SIES, four donor institutions - the International Financial Corporation, the European Investment Bank (EIB), the French Development Bank and the French Development Fund - and the Senegalese government was signed. The costs ran to more than three billion Francs CFA, of which the EIB supplied a share of 600 million F CFA. The Community's Production Aid Programme, with its enigmatic modernization plan for the peanut economy and extremely optimistic consumption forecasts,

${ }^{28}$ République du Sénégal, Les orientations générales du plan quadriennal 1961-1964, Dakar: République du Sénégal (1963), p. 86; Comité du FAC, 'Prêt spéciale à la société industrielle d'engrais au Sénégal', May 1966, Centre d'accueil et de recherches des Archives Nationales (CARAN), Fonds Foccart public (FPU), p. 237; see also Guy Rocheteau, Pouvoir financier et indépendance économique en Afrique. Le cas du Sénégal, Paris: Karthala (1982), p. 241; complex fertilizer contains several nutritive substances in contrast to simple fertilizer, and hence requires a more elaborate process of manufacture.

${ }^{29}$ On details of this programme, see Martin Rempe, 'Fit für den Weltmarkt in fünf Jahren? Die Modernisierung der senegalesischen Erdnusswirtschaft in den 1960er Jahren', in: Hubertus Büschel and Daniel Speich (eds.), Entwicklungswelten. Globalgeschichte der Entwicklungszusammenarbeit, Frankfurt a. M.: Campus (2009), pp. 241-273.

${ }^{30}$ DG VIII, 'Exposé du programme quinquennal d'aide à la production du Sénégal', 21 December 1964, Archives of the Delegation of the EU in Senegal (ADEUS) II. FED 214015032; République du Sénégal 1963, p. 86; Comité du FAC, 'Prêt spéciale à la société industrielle d'engrais au Sénégal', May 1966, CARAN, FPU, p. 237. 
was a component of critical investment-security for some creditors. Especially the French fund, but also the EIB, trusted the planners of the DG VIII so much that the European bank seemingly deemed it unnecessary to make direct inquiries in Brussels. However, this blind confidence may also be explained by the donor's successful campaign for a purchase guarantee: the Senegalese government was obligated to buy 60,000 tons of fertilizer per year, an amount large enough to make the investment profitable for the investors, regardless of the actual demand. ${ }^{31}$

When the purchase guarantee came into effect in 1968, the modernization programme of the EEC had not fulfilled the great expectations placed on it. On the contrary, the Senegalese peanut economy was deep in crisis due to climatic reasons, the failure of structural reforms imposed by Senegalese government and the effects of hasty modernization and liberalization caused by the Production Aid Programme itself. ${ }^{32}$ The 'malaise paysan', as the return to subsistence economy was called, spread among the peasants ${ }^{33}$ and those who continued to cultivate cash crop had no money to buy fertilizer. In 1968, the heyday of the grève d'engrais, ${ }^{34}$ the estimated demand decreased to less than 20,000 tons of fertilizer.

In this situation, Senegal's president Leopold Senghor came up with a controversial proposal for the last tranche of the fertilizer subventions: apply for much more money than originally planned for the purpose of both subsidizing fertilizer and accounting for the penalty the Senegalese government had to pay vis-à-vis the SIES. What was more, Senghor's concept required direct contracting with the Senegalese company in place of a regular call for tenders. ${ }^{35}$

This proposition met little support in Brussels for several reasons. Firstly, the DG VIII did not feel responsible for the penalty, which was

${ }^{31}$ Comité du FED, 'Compte rendu de la 61ème reunion', 12 May 1969, HAEU 38/1984-153, p. 193, here 220; Comité du FAC, 'Prêt spéciale à la société industrielle d'engrais au Sénégal', May 1966, CARAN, FPU, p. 237.

${ }^{32}$ Yves Péhaut, 'De l'O.C.A à la SONACOS. Vingt ans d'échec des structures de commerce de l'arachide du Sénégal', Année Africaine (1982), pp. 407-431; John Waterbury, 'Dimensions of State Intervention in the Groundnut Basin', in: Mark Gersovitz (ed.), The Political Economy of Risk and Choice in Senegal, London: Cass (1987), pp. 188-222.

${ }^{33}$ On the malaise paysan, Edward J. Schumacher, Politics, Bureaucracy, and Rural Development in Senegal, Berkeley, CA: University of California Press (1975), pp. 183-185.

${ }^{34}$ Note 'Le placement et la production de l'engrais', not dated [1968], Centre des Archives Contemporaines (CAC) 19950347-55, vol. 2.

${ }^{35}$ Instead of applying for the planned 250 million, he applied for 650 million F CFA. 'Hendus to Rochereau', 12 February 1969, HAEU 25/1980-657, p. 23. 
exacted for non-compliance to the purchase guarantee. Secondly, conflicts about the distribution of contracts were generally at the heart of the European development policy for years. Thirdly, the fertilizer applications of the earlier tranches led to discussions between the member states and the Commission, since some countries' fertilizer industries felt discriminated against. Indeed, this conflict led to the generation of a 'scheme for allowable aberrations', ${ }^{36}$ which, however, was only valid for tenders of the EDF. A European agreement on the comparability of fertilizers was only signed after long lasting negotiations in $1975 .{ }^{37}$ Obviously, the mixture of fertilizers was not as unimportant as the member states had claimed with respect to the scheme laid out in European development policy nearly ten years before. Again, it seemed like the interests of European industries were more important than the provision of the best-suited fertilizer to Senegalese peanut farmers. Against this backdrop, it is not surprising that all member states but France vetoed the planned, single tender action in favour of the SIES. The Commission, however, being completely aware of the situation's urgency, ignored the decision of the EDF committee and concluded the contract with the Senegalese enterprise. ${ }^{38}$

Nevertheless, this move alone did not much help in getting the Senegalese government out of its plight. On the one hand, the demand lagged far behind the estimated amount, despite the high subventions for the fertilizer. On the other hand, it was the last tranche of the Community's five-year production aid programme, which also meant the end of fertilizer subsidies. As a result, at the beginning of the 1970s, the SIES bestowed an additional and considerable financial obligation on the Senegalese state at a time when the domestic demand for fertilizer was at a ten-year low. This case serves as a striking example for the fact that the failure of development projects had considerable effects on developing countries. What is more, the establishment of the SIES shows that the EEC was much more involved in industrial development in Africa than the bare figures of the EDF or EIB indicate at first glance. Finally, the case significantly shows, again, how much resistance

${ }^{36}$ DG VIII, 'Vermerk', March 1966, HAEU 25/1980-515, p. 5; the problem was to determine 'the equivalence between fertilizers whose mixture of nutritive elements differ from each other'.

37 'Richtlinie 76/116 des Rates zur Angleichung der Rechtsvorschriften der Mitgliedsstaaten für Düngemittel', Amtsblatt der Europäischen Gemeinschaften L no. 24, 30 January 1976 , pp. 21-44.

${ }^{38}$ Rempe (2012), Entwicklung im Konflikt, p. 219 f. 
an import substitution approach met from the industrialized European countries. The inconsistency of the Community's industrial development policy was primarily the result of the differing attitudes and behaviour between the European Commission and the EEC member states.

This divide between the Commission and the member states was not restricted to the import substitution approach, but manifested as well in the 1970s, when the Senegalese government embarked on an export-oriented industrialization strategy. The foundation of an industrial export processing zone (EPZ) came to be a pet project for President Senghor. The original idea for the establishment of an EPZ near Dakar, however, was birthed in Paris. The department for African Affairs of the Quai d'Orsay wanted to facilitate access to Latin American markets for French and other European enterprises. It was assumed that a settlement in Dakar would not only be geographically much closer to Latin America, but could also be advantageous in terms of labour costs. ${ }^{39}$ In contrast, the Federal Republic judged the economic value of such an industrial zone to be rather marginal for its own economy. Hence, when Senghor asked for German support in 1970, Chancellor Willy Brandt reacted cautiously, and argued that due to the size of the project, the foundation of the zone would require a European initiative. ${ }^{40}$

Despite Germany's reluctance, the Senegalese government stuck to its guns and was conceptually backed by the Commission. Indeed, the EPZ fit perfectly with the new general survey of the DG VIII on export-oriented industries. The Senegalese Minister for industry Daniel Cabou took advantage of this correspondence and selected one of the Commission's drafts as the key justification for his own project. In a preliminary study intended for the French development ministry, Cabou cited the following from the European draft: 'The best measure to attract foreign investors is to provide special sites for their settlements, that is, well-suited and highly developed export processing zones. ${ }^{41}$

Once more, the discrepancy between the recommendations of European experts and political action of the member states became obvious. Germany did not change its sceptical attitude, and France, meanwhile, had reconsidered its position, not least because it became clear that, due

\footnotetext{
39 'Senghor to Pompidou', 23 April 1970, AMAEF Sénégal 93; 'Réunion chez Dechamps' [handwritten protocol of the meeting of the ad hoc group], 10 August 1970, in: Rempe (2012), Entwicklung im Konflikt.

${ }^{40}$ Secrétaire d'état de la Coopération, 'Compte rendu d'entretien "Port franc du Cap Vert"', 9 August 1970, AMAEF Sénégal 93.

41 'Cabou to Bourges', 14 January 1972, Annex: Étude de marché complémentaire, CAC 19950347-53.
} 
to a very investor-friendly regular commercial law, the formation of a Senegalese export processing zone would barely add any advantages for foreign enterprises. ${ }^{42}$

It all ended in the following division of labour: Senegal took over the general planning and France and the FRG became responsible for special preliminary surveys. The DG VIII was supposed to give special attention to the export processing zone when conducting the sector studies of its general survey. In short, the European partners engaged in further knowledge production and feasibility studies, but stayed away from any capital investment. Finally, the establishment of the export processing zone was achieved in 1976 with money from the Iranian development fund. ${ }^{43}$

\subsection{Conclusion}

Some general conclusions can be drawn from the Senegalese experience. First of all, the three cases together make clear that the EEC had been, already in the 1960s and early 70s, much more influential in African endeavors of industrial development than the official record of the European Development Fund suggests. Even looking at a country such as Senegal, which, at first glance, appears to have barely been touched by the EEC in terms of industrialization, still shows that the Community more often than not had a finger in the pie when the Senegalese state seized the initiative in the industrial sector. More generally, this observation can be put forward as a strong argument in favour of conducting historical investigations that take both ends of the development cooperation into account in a more systematic fashion. ${ }^{44}$

Secondly, the combination of the Community's concepts on industrial development is, to some extent, surprising, at least from a global perspective. It is not so much the dominance of the import-substitution

\footnotetext{
${ }^{42}$ Secrétaire d'état de la Coopération, 'Note pour la direction des affaires africaines et malgaches', 11 September 1971, AMAEF Sénégal 93; on the Senegalese code of investments see Jean-Claude Gautron, 'Les conventions d'établissement conclues par le Sénégal avec des entreprises', Annuaire français de droit international 14 (1968), pp. 654-670.

${ }^{43}$ Huybrechts, 'Rapport de mission', not dated [1972], HAEU 25/1980-1487, p. 12; 'Bulletin développement industriel', July/October 1976, CAC 1995034753; Rocheteau (1982), Pouvoir financier et indépendance économique, p. 372; the sector studies of the community were finished only in 1975, 'Krohn to Lebsanft', 20 January 1975, HAEU 25/1980-1986, p. 261.

${ }^{44}$ See as well Andreas Eckert, 'Nachwort', in: Büschel and Speich (2009), Entwicklungswelten, pp. 311-319.
} 
approach in the 1960s which is astonishing, even if one argues that the problems of Prebisch's theory were already well-known at that time. ${ }^{45}$ More striking is the focus on export-oriented industrialization at the beginning of the 1970s, at a time when the global development discourse highlighted education, health, nutrition and the so-called basic needs approach as absolute priorities. Given that not only Senegal, but many other developing countries deliberately embarked on this exportoriented strategy - in 1975, around 80 developing countries had an operational export processing zone - it would seem that the picture of the second development decade with its allegedly social focus has to be reassessed. ${ }^{46}$

Third, the cases shed some light on external factors that blocked industrialization in Senegal. The Senegalese government was caught in a dilemma between investors' demands for considerable privileges and international trade obligations, and between the need of attracting foreign investment and the reluctance of European member states. Ignoring the developmental expertise of the European Commission, the latter vehemently protected the industrial status quo and defended the existing international division of labour. Accordingly, the export processing zone did not attract many investors either; and, after few years, it was deemed a failure. ${ }^{47}$ Nevertheless, one should not conclude that entangled industrial development efforts were regularly doomed to fail. For example, it seems that the Ivory Coast was more successful in the 1960s and 70s in using Community means and assistance in order to foster its agro-industrial sector. ${ }^{48}$ In conclusion, industrial development

${ }^{45}$ For example, see the criticism in Donges and Müller-Ohlsen (1978), Außenwirtschaftsbeziehungen und Industrialisierung.

${ }^{46}$ Hubertus Büschel, 'Geschichte der Entwicklungspolitik', DocupediaZeitgeschichte, 11 February 2010, http://docupedia.de/zg/Geschichte_der_ Entwicklungspolitik, (date accessed3 May 2012); Gilbert Rist, 'The History of Development. From Western Origins to Global Faith', 3rd edn. London: Zed Books (2008), pp. 140-170; Folker Fröbel, Jürgen Heinrichs and Otto Kreye, 'Die neue internationale Arbeitsteilung. Strukturelle Arbeitslosigkeit in den Industrieländern und die Industrialisierung der Entwicklungsländer', Reinbek: Rowohlt (1977), p. 493.

${ }^{47}$ Dirk Vieser, Ausländische Privatinvestitionen im Senegal. Eine Fallstudie über Struktur, Rahmenbedingungen und Auswirkungen in einem AKP-Land, Berlin: Duncker \& Humblot (1982), p. 77.

${ }^{48}$ Helga Gerth-Wellmann and Dorothee Kayser, Die industrielle Zusammenarbeit zwischen der EG und den AKP-Staaten im Rahmen der Lomé-Politik. Empirische Analyse und Versuch einer Einschätzung, München: Weltforum (1980), pp. 73 f., 115-130. 
cooperation between the EEC and its associated African countries, for better or for worse, represents a shared history, which must be taken into account when studying the history of industrial policy in Africa.

\section{References}

Bayart, Jean-François, 'Africa in the World: A History of Extraversion', African Affairs 99 (2000), pp. 217-267.

Büschel, Hubertus, 'Geschichte der Entwicklungspolitik', Docupedia-Zeitgeschichte, 11.2.2010, http://docupedia.de/zg/Geschichte_der_Entwicklungspolitik (accessed 3 May 2012).

Calzadilla, Bernardo and Andreas Novy, 'Importsubstituierende und exportorientierte Industrialisierung', in: Feldbauer, Peter (ed.), Industrialisierung: Entwicklungsprozesse in Afrika, Asien und Lateinamerika, Frankfurt a.M.: Brandes \& Apsel (1995), pp. 33-46.

Chafer, Tony, The End of Empire in French West Africa: France's Successful Decolonization, Oxford/New York: Berg (2002).

Clapham, Christopher, Africa and the International System: The Politics of State Survival, Cambridge: Cambridge University Press (1996).

Cooper, Frederick, Africa since 1940. The Past of the Present, Cambridge: Cambridge University Press (2002).

Cosgrove-Twitchett, Carol, Europe and Africa: From Association to Partnership, Farnborough: Saxon House (1978).

Diouf, Mamadou, 'Senegalese Development. From Mass Mobilization to Technocratic Elitism', in: Cooper, Frederick and Randall Packard (eds.), International Development and the Social Sciences: Essays on the History and Politics of Knowledge, Berkeley: University of California Press (1997), pp. 291-319.

Donges, Jürgen and Lotte Müller-Ohlsen, Außenwirtschaftsbeziehungen und Industrialisierung in Entwicklungsländern, Tübingen: Mohr (1978).

Eckert, Andreas, 'Nachwort', in: Büschel, Hubertus and Daniel Speich (eds.), Entwicklungswelten: Globalgeschichte der Entwicklungszusammenarbeit, Frankfurt a. M.: Campus (2009), pp. 311-319.

Foreman-Peck, James and Giovanni Federico (eds.), European Industrial Policy: The Twentieth Century Experience, Oxford: Oxford University Press (1999).

Fieldhouse, David K., Black Africa 1945-80: Economic Decolonization and Arrested Development, London: Allen \& Unwin (1986).

Fröbel, Folker, Jürgen Heinrichs and Otto Kreye, Die neue internationale Arbeitsteilung: Strukturelle Arbeitslosigkeit in den Industrieländern und die Industrialisierung der Entwicklungsländer, Reinbek near Hamburg: Rowohlt (1977).

Gautron, Jean-Claude, 'Les conventions d'établissement conclues par le Sénégal avec des entreprises', Annuaire français de droit international 14 (1968), pp. 654-670.

Gerth-Wellmann, Helga and Dorothee Kayser, Die industrielle Zusammenarbeit zwischen der EG und den AKP-Staaten im Rahmen der Lomé-Politik: Empirische Analyse und Versuch einer Einschätzung, München: Weltforum (1980).

Graf, Rüdiger and Kim Christian Priemel, 'Zeitgeschichte in der Welt der Sozialwissenschaften. Legitimität und Originalität einer Disziplin', Vierteljahrshefte für Zeitgeschichte 26 (2011), pp. 479-508. 
Grilli, Enzo R., The European Community and the Developing Countries, Cambridge: Cambridge University Press (1993).

Kerr, Clark, Industrialism and Industrial Man: The Problems of Labour and Management in Economic Growth, London: Heinemann (1962).

Marseille, Jacques, Empire colonial et capitalisme français: histoire d'un divorce, Paris: Albin (1984).

Migani, Guia, La France et l'Afrique sub-saharienne, 1957-1963: histoire d'une décolonisation entre idéaux eurafricains et politique de puissance, Brussels: Lang (2008).

Moser, Thomas, Europäische Integration, Dekolonisation, Eurafrika: Eine historische Analyse über Entstehungsbedingungen der Eurafrikanischen Gemeinschaft von der Weltwirtschaftskrise bis zum Jaunde-Vertrag, 1929-1963, Baden-Baden: Nomos (2000).

O' Brien, Patrick K., 'Industrialization', in: Bentley, Jerry H. (ed.), The Oxford Handbook of World History, Oxford: Oxford University Press (2011), pp. 304-324.

Péhaut, Yves, 'De l'O.C.A à la SONACOS: Vingt ans d'échec des structures de commerce de l'arachide du Sénégal', Année Africaine 1982, pp. 407-431.

Rempe, Martin, 'Fit für den Weltmarkt in fünf Jahren? Die Modernisierung der senegalesischen Erdnusswirtschaft in den 1960er Jahren', in: Büschel, Hubertus and Daniel Speich (eds.), Entwicklungswelten. Globalgeschichte der Entwicklungszusammenarbeit, Frankfurt a. M.: Campus (2009), pp. 241-273.

Rempe, Martin, 'EEC Industrialization Plans for Africa in the Sixties', in: di Sarcina, Federica, Laura Grazi and Laura Scichilone (eds.), Res Europae: Attori, Politiche e Sfide dell'Integrazione Europea, Florence: Centro Editoriale Toscano (2010), pp. 107-118.

Rempe, Martin, Entwicklung im Konflikt. Die EWG und der Senegal 1957-1975, Köln: Böhlau (2012).

Rempe, Martin and Tillmann Schneider, '50 Jahre "Europa" in Westafrika: Zum Verhältnis europäischer und westafrikanischer Integration', in: Pernice, Ingolf et al. (eds.), Europa jenseits seiner Grenzen: Politologische, historische und juristische Perspektiven, Berlin: Nomos (2009), pp. 37-52.

République du Sénégal, Plan quadriennal de développement, 1961-1964, Dakar: République du Sénégal (1961).

République du Sénégal, Les orientations générales du plan quadriennal 1961-1964, Dakar: République du Sénégal (1963).

République du Sénégal, Deuxième Plan quadriennal de développement économique et social, Dakar: République du Sénégal (1965).

Rist, Gilbert, The History of Development: From Western Origins to Global Faith, 3rd ed., London: Zed Books (2008).

Rocheteau, Guy, Pouvoir financier et indépendance économique en Afrique. Le cas du Sénégal, Paris: Karthala (1982).

Rostow, Walt W., Stadien wirtschaftlichen Wachstums: Eine Alternative zur marxistischen Entwicklungstheorie, Göttingen: Vandenhoeck \& Ruprecht (1960).

Schumacher, Edward J., Politics, Bureaucracy, and Rural Development in Senegal, Berkeley: University of California Press (1975).

Sieberg, Herward, Colonial Development: Die Grundlegung moderner Entwicklungspolitik durch Großbritannien 1919-1949, Stuttgart: Steiner (1985).

Tooze, Adam J., 'Die Vermessung der Welt. Ansätze zu einer Kulturgeschichte der Wirtschaftsstatistik', in: Berghoff, Hartmut and Jakob Vogel (eds.), 
Wirtschaftsgeschichte als Kulturgeschichte. Dimensionen eines Perspektivenwechsels, Frankfurt a. M.: Campus (2004), pp. 325-351.

Vahsen, Urban, Eurafrikanische Entwicklungskooperation: Die Assoziierungspolitik der EWG gegenüber dem subsaharischen Afrika in den 1960er Jahren, Stuttgart: Steiner (2010).

Vieser, Dirk, Ausländische Privatinvestitionen im Senegal: Eine Fallstudie über Struktur, Rahmenbedingungen und Auswirkungen in einem AKP-Land, Berlin: Duncker \& Humblot (1982).

Waterbury, John, 'Dimensions of State Intervention in the Groundnut Basin', in: Gersovitz, Mark (ed.), The Political Economy of Risk and Choice in Senegal, London: Cass (1987), pp. 188-222. 